Article

\title{
Algorithm for Selecting Best Available Techniques in Polish Coking Plants Supporting Multi-Criteria Investment Decisions in European Environmental Conditions
}

\author{
Jolanta Telenga-Kopyczyńska ${ }^{1}$ and Izabela Jonek-Kowalska ${ }^{2, *(\mathbb{D})}$ \\ 1 Institute for Chemical Processing of Coal, Zamkowa Street 1, 41-803 Zabrze, Poland; jtelenga@ichpw.pl \\ 2 Faculty of Organization and Management, The Silesian University of Technology, 41-800 Zabrze, Poland \\ * Correspondence: izabela.jonek-kowalska@polsl.pl; Tel.: +48-32-2777336
}

check for

updates

Citation: Telenga-Kopyczyńska, J.; Jonek-Kowalska, I. Algorithm for Selecting Best Available Techniques in Polish Coking Plants Supporting Multi-Criteria Investment Decisions in European Environmental Conditions. Energies 2021, 14, 2631. https://doi.org/10.3390/en14092631

Academic Editor: Athanasios

I. Papadopoulos

Received: 4 April 2021

Accepted: 30 April 2021

Published: 4 May 2021

Publisher's Note: MDPI stays neutral with regard to jurisdictional claims in published maps and institutional affiliations.

Copyright: (c) 2021 by the authors. Licensee MDPI, Basel, Switzerland. This article is an open access article distributed under the terms and conditions of the Creative Commons Attribution (CC BY) license (https:/ / creativecommons.org/licenses/by/ $4.0 /)$.

\begin{abstract}
The tightened approach of the European Commission to the issue of meeting the levels of pollutant emissions to the environment, inextricably connected with the level of technology used, is a serious financial challenge for many European coke producers, therefore the main aim of the article is to develop an algorithm of conduct that allows a selection of the best available emission abatement techniques from the coking plant in conditions with multiple emission sources, taking into account technological, environmental, and economic criteria. This algorithm can be used as a universal tool supporting production managers in planning investments limiting the environmental impact of the coking plant in the most economically advantageous way, while using BAT techniques. In the development of the algorithm, a multi-criteria analysis and a scenario method were used, as well as a number of typical methods for measuring and reducing the level of emissions in the coke production process. Its demonstration and verification were carried out within ten investment scenarios prepared for a selected coking plant. The presented method of selecting the optimal scenario is universal and allows for a flexible selection of weights for the criteria depending on the needs and limits of the investor at a given time or to long term plans to adapt to the increasingly tightening environmental requirements. This method can also be used in discussions with the authorities issuing integrated permits as regards the deadlines for adapting to legal requirements.
\end{abstract}

Keywords: best available techniques; coking plants; reduction of air pollution; investment decision support systems

\section{Introduction}

For many years Poland has been indicated in Europe as the country with the most polluted air, which in particular refers to dust pollution. In the last report of the Environmental Protection Agency in Poland, the highest BaP concentration was recorded, a value of $18.3 \mathrm{ng} / \mathrm{m}^{3}$ with the permissible concentration of $1 \mathrm{ng} / \mathrm{m}^{3}$ [1]. It is true that the main source of this pollution is individual heating, which still uses hard coal as an energy fuel, but the industrial sector is also largely responsible for its emission. In the regional and local perspective, $\mathrm{BaP}$ emission is particularly intense in the areas where coke production is located. There are currently eight coking plants (works) in Poland, including five plants in the Silesia Province, where the permissible BaP concentration is regularly and frequently recorded.

In response to the growing level of threats related to industrial production not only in Poland, but also in other European countries, the European Union in 1996 introduced legal regulations for industrial plants, aimed at unifying environmental requirements for production plants. The first action in this regard was the introduction of Directive 96/61/EC on the Integrated Pollution Prevention and Control (IPPC), which was one of the most important legal acts of the European Union in the field of environmental protection. The requirements of the Council Directive 96/61/EC on the Integrated Pollution Prevention 
and Control were transposed into Polish legislation in 2001. Act-Environmental Protection Law (EPL). According to its provisions, from 1 January 2002, the requirement to obtain integrated permits for the operation of plants covered by IPPC was introduced. The introduction of integrated permits meant a significant change in the approach to issuing environmental permits, which until now the negative aspects of industrial production such as: air emission, noise, sewage discharge, waste management, or radiation emission had been dealt with separately. The purpose of introducing the system of integrated permits was to lead to a significant and systematic improvement of the state of the environment in the EU, and at the same time to unify the requirements throughout the EU and thus prevent the migration of so-called dirty technologies to countries where environmental protection requirements would be less severe.

Along with the integrated permit, the concept of the Best Available Techniques (BAT), and coking plants as installations included in the IPPC installations have been obliged to obtain an integrated permit, which not only regulates the conditions of using the environment, but also the rules of running a business. Failure to obtain the required integrated permit results in the suspension of operations. In the integrated permit, the authority competent to issue it defines the conditions for conducting business activity so that they comply with the requirements of the best available technique, the so-called BAT and ensured maximum environmental protection.

Additionally, as part of organizing EU law, the European Parliament and the Council on 24 November 2010 adopted Directive 2010/75/EU on industrial emissions (IED-The Industrial Emissions Directive). On 6 January 2011, the arrangements contained in the above-mentioned directives become binding in all member states. The Industrial Emissions Directive contains new rules and obligations related to the procedure of obtaining and verifying the conditions of an integrated permit, which have been implemented into Polish law. The EC decided to place particular emphasis on unifying the practice of applying BREFs in individual Member States (BREF: Best Available Technique (BAT) Reference Document), in particular by introducing the provisions of BAT conclusions, which are an excerpt from the BREF reference document. Conclusions are adopted by decision of the European Commission, and then published in all official EU languages and directly constitute binding legal acts. This means that the emission values specified therein, and the equivalent technical parameters constitute the legal standard that should be included in the integrated permit.

The stricter approach of the European Commission to the issue of meeting the levels of pollutant emissions to the environment, inextricably linked with the level of the technology used, is a serious financial challenge for many European coke producers. Adapting to the provisions of the conclusions required and still requires significant investment expenditures on the part of plant operators. At the same time, it is worth emphasizing that production managers must not only take into account the currently applicable environmental standards, but also the increasing tendency to enforce them. The growing ecological awareness of the society and independent pro-ecological environments play an increasingly important role in the decision-making process, as well as the increase in their requirements in terms of reducing the negative impact of coal processing on air quality and human health [2,3]. The above-mentioned circumstances complicate the selection of the best available emission abatement techniques, as they require the simultaneous consideration of technical, environmental, and economic criteria, both in the current and perspective terms.

Therefore, the final selection of techniques with specific investment expenditures should be preceded by an analysis of environmental benefits in order to indicate the most effective solutions taking into account all the mentioned criteria. Meanwhile, at present, when selecting techniques to reduce emissions in industrial plants, the simplest scheme of conduct is often used in theory and practice, which consists in selecting the technique with the highest environmental efficiency for a single emitter without taking into account the simultaneous occurrence of many emission sources accompanying individual stages of coke production. Thereafter, only the cost reduction achieved by the selected technique 
is determined. This approach does not allow identifying the holistic and real impact of the plant as a whole on air quality. As a consequence, it also does not allow for the choice of other techniques, often less effortless and cost-intensive, ensuring a similar ecological effect. This problem also remains unsolved in the literature on the subject.

Bearing in mind the described legal and environmental conditions as well as theoretical and practical difficulties related to the selection of BAT when considering the coking plant as a whole, this article seeks answers to the following research problem: How to identify, select, and choose BAT taking into account the multi-emission nature of coke production and multi-criteria decisions made in this regard (environmental, economic, and technological criteria)? The main aim of the considerations is to develop an algorithm of conduct that enables the selection of the best available techniques to reduce emissions from the coking plant (works) in the conditions of multiple emission sources, taking into account technological, environmental, and economic criteria. The algorithm is to be a universal tool supporting production managers in planning investments limiting the environmental burden of the coking plant in the most economically advantageous way, while using BAT techniques.

\section{Literature Studies}

\section{Sources of Environmental Burden in Coke Production}

The activity of coking plants can be classified as one of the most environmentally burdensome industrial sectors [4,5]. The coke production process is accompanied by captured and fugitive emission of gaseous and dust pollutants [6]. Captured emission occurs when substances are introduced into the air in a controlled manner through the emitter (stack) and it is measurable by standard measurement methods. Fugitive emission is emission that is not measurable by known measurement methods [7]. The process of coke production is accompanied by the release of many air pollutants into the air, including very harmful ones-carcinogenic [8].

The coal plant is the first area of the coking plant and it prepares the coal blend for the coking process in the coke battery. The processes of unloading, grinding, transporting, and storing coal are the main source of coal dust emissions. In the case of open landfills, we deal with the phenomenon of secondary dusting caused by wind and vehicles. The prepared coal blend is directed to the coal tower on the coke battery and then to the charging or feeding machine, depending on the method of filling the battery [9]. Moreover, in the winter period, the source of emission of coke oven gas combustion products is additionally the coal thawing process. The emissions of pollutants from the coking process in the coke oven plant are synthetically presented in Figure 1.

The task of the coke oven is to produce coke from a coal blend prepared in the coal plant. Coke batteries are the main source of pollutant emissions from coking plants, which emit flue gas, raw coke oven gas and dust into the air, which account for $75-95 \%$ of the total dust and gas emissions from these plants [10]. The coke production process is characterized by fugitive emissions mainly coming from leaking batteries (doors, charging holes, and ascension pipes) during coking or emissions accompanying the process of filling the battery and pushing coke in the absence of a dedusting system. This emission is difficult to avoid even using the best available techniques. Fugitive emissions are mainly dust, $\mathrm{PAH}$, and benzene emissions [11-15]. 


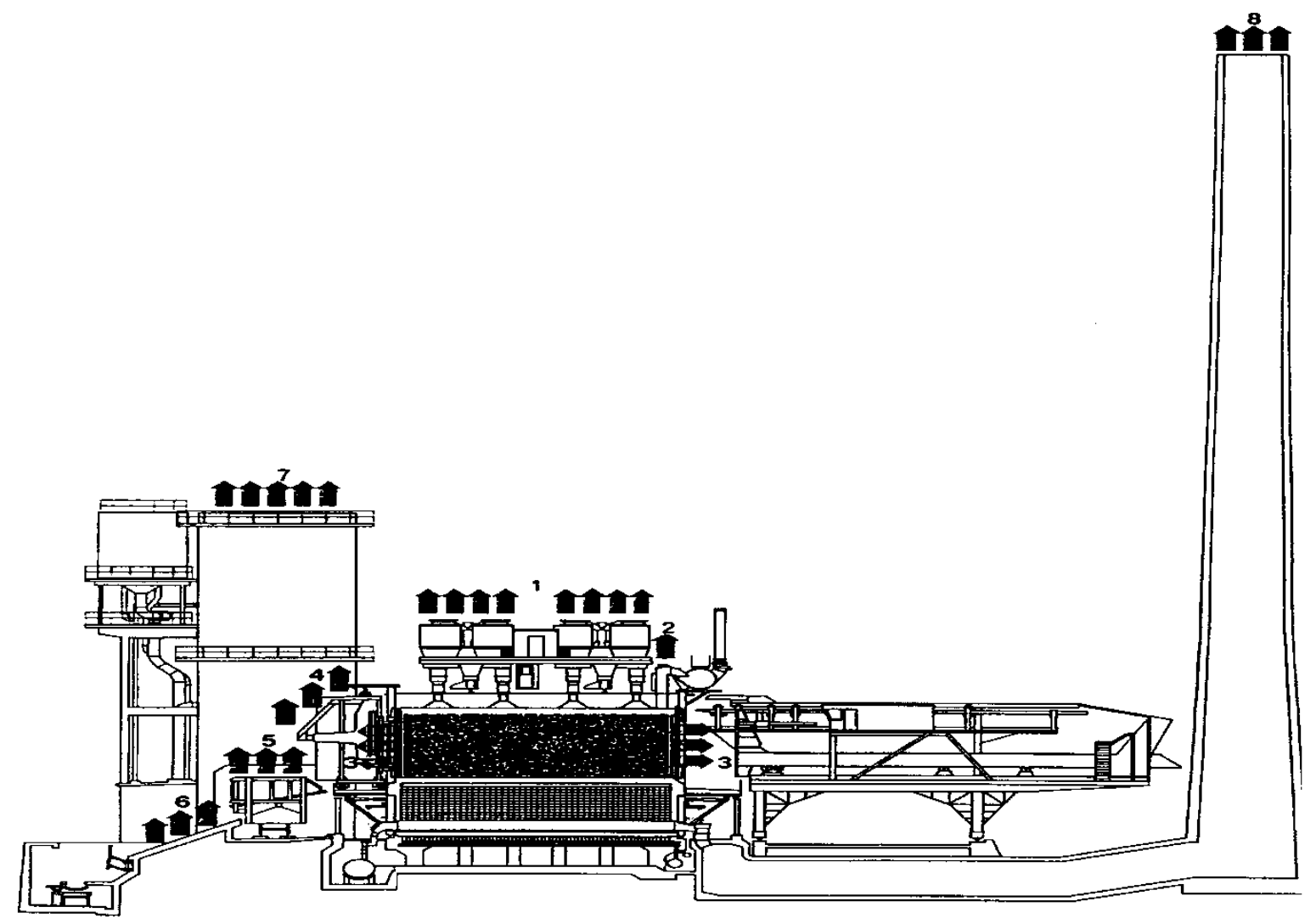

Figure 1. Sources of air pollutant emissions from the coal coking process for the coke battery operating in the charging system with wet coke quenching. Source: own elaboration.

On the other hand, the sources of captured emission include the coke battery firing stack, the quench tower and dedusting chimneys. The most important pollutants that are emitted from the combustion process are: dust, $\mathrm{NOx}, \mathrm{SOx}$, and $\mathrm{CO}_{2}$ [16]. Dust is also emitted during the quenching process and from the dedusting plant during the pushing of coke. During the coal coking process, approx. $300-400 \mathrm{~m}^{3}$ of coking gas per each $\mathrm{Mg}$ of coal are produced in the coking chamber. The gas is completely discharged with extraction equipment to the coal by-product plant in order to clean the coke oven gas. Depending on the technical condition of the battery, up to $1-5 \%$ of the produced gas may be emitted (fugitive emission) into the atmosphere through leaks in the coke battery (doors, technological holes, and leaks in the ceramic brickwork) (Figure 1).

In Poland, coke batteries are heated by the combustion of coke oven gas and the exhaust gases are emitted (fugitive emission) into the air through a firing stack [17]. The coke pushing process is associated with fugitive emission of pollutants, mainly dust, in the absence of a dedusting system from the coke side. This emission is variable and depends on the degree of coke baking and applied technological solutions. In the case of applying methods limiting the emission of pollutants from the coke pushing process, we deal with dust emission from the coke side dedusting plant (Figure 2).

Another source of fugitive emission of pollutants is the coke cooling (quenching) process. When wet quenching of coke is used, vapors, as well as solid, liquid, and gaseous air pollutants are emitted from the quenching tower, in varying amounts and concentrations over time. Vapors rising above the train car and getting to the quench tower carry with them fine grain fractions of coke dust and other pollutants generated in the coke cooling process $[18,19]$. The amount of dust entrained depends on the process conditions, the properties of the coke, the way in which the water is introduced, and the abatement equipment used. In the process of dry cooling of coke, the amount of dust emission to air depends on the effectiveness of dedusting equipment [7] (Figure 3). 


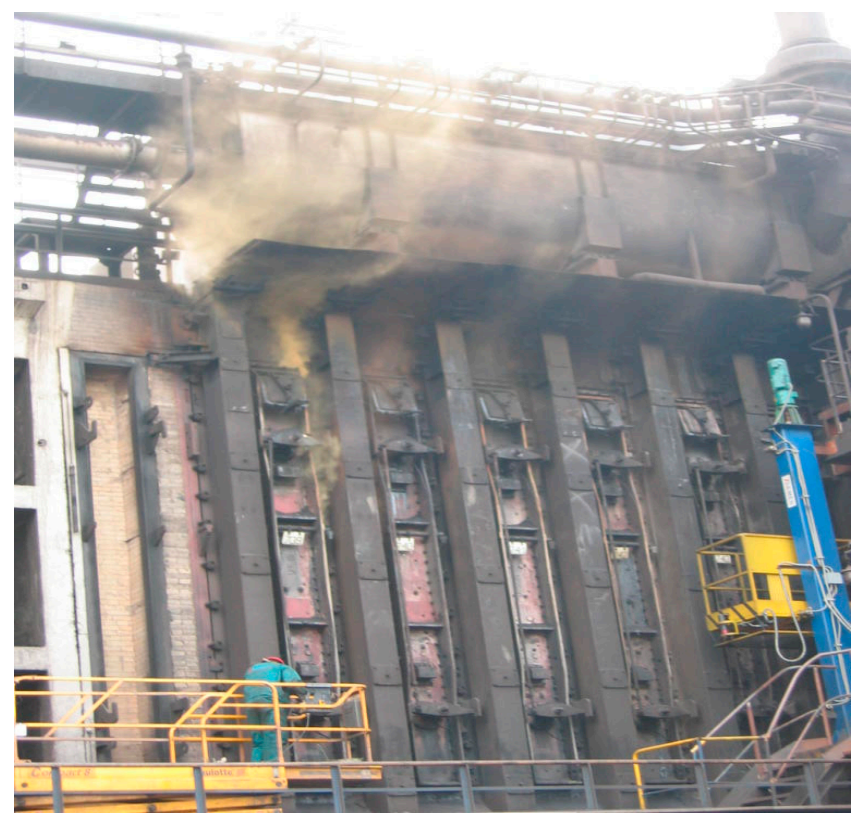

Figure 2. Fugitive emission from leaks in the coke battery door. Source: Instytut Chemicznej Przeróbki Węgla (IChPW; Institute for Chemical Processing of Coal) materials from the implementation of the project 'Intelligent coking plant meeting the requirements of the best available technology'.

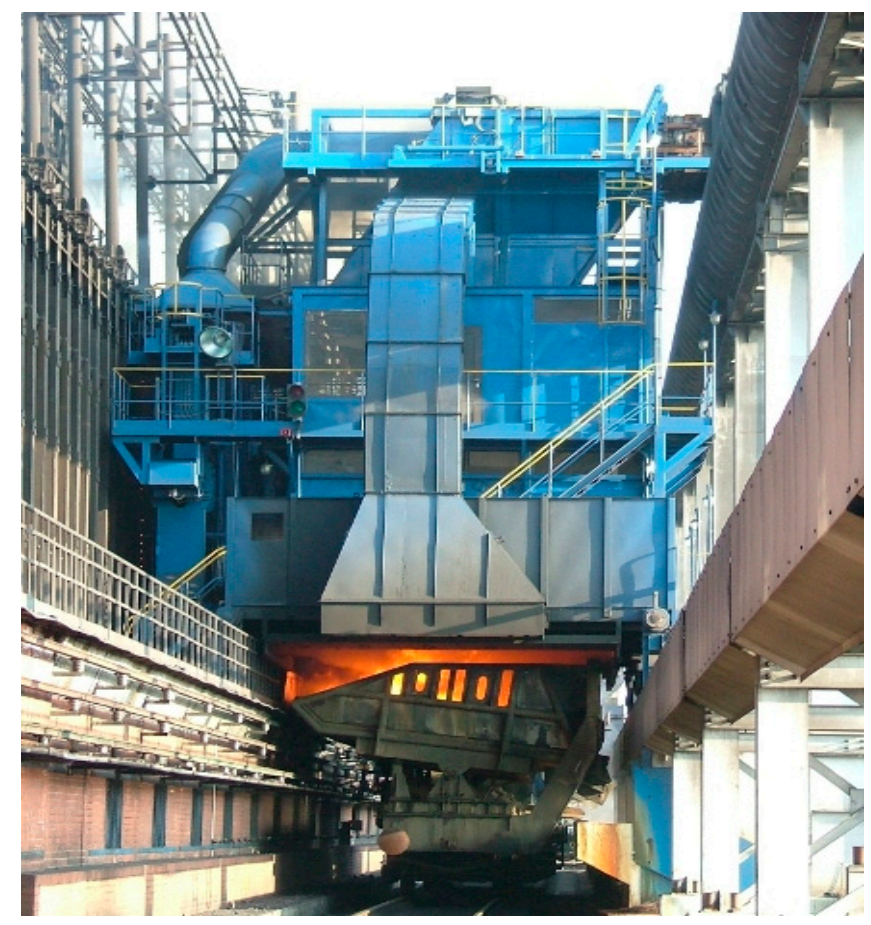

Figure 3. Dedusting system on the coke side. Source: Instytut Chemicznej Przeróbki Węgla (IChPW; Institute for Chemical Processing of Coal) materials from the implementation of the project 'Intelligent coking plant meeting the requirements of the best available technology'.

The main task of the coal by-product plant is the treatment of raw coke oven gas. The amount and type of pollutants emitted from this plant mainly depend on the technical condition and the degree of air-tight sealing of the equipment, and it is mainly fugitive emission from leaks in process lines, pumps, and apparatus, and from loading operations of carbon-based products. During the recovery of carbon-based products, limitation of 
their release into the air can be achieved by such measures as air-tight sealing of tanks, machines, pipelines, and fittings.

In the process of offtake and treatment of volatile coking products, air pollutants may be emitted, including, among others: coke oven gas components of different composition depending on the place of its emission, ammonia from the ammonia separation area, benzene and its derivatives from the benzene production plant, polycyclic aromatic hydrocarbons [20], as well as phenol, hydrogen sulfide, and combustion products of excess coke oven gas in a flare stack. The sources of dust emissions are also the operations of grinding and screening coke in the sorting plant and coke storage in an open storage site. Table 1 as a summary of the considerations on the environmental burden of coke production-lists the sources of fugitive and captured emissions by coking plants, in which subsequent stages of coke production are carried out [21].

Table 1. Descriptive statistics for labour productivity in examined coal mines (in Mg per employee).

\begin{tabular}{|c|c|c|}
\hline & Fugitive Emission & Captured Emission \\
\hline Plant & Source of Emission & \\
\hline Coal plant & Preparation of the coal charge. & $\begin{array}{l}\text { Dedusting of coal pulverizers and } \\
\text { buildings and transfer stations. } \\
\text { Thawing wagons. }\end{array}$ \\
\hline Coke oven & Filling, coking, pushing. & $\begin{array}{l}\text { Firing of the coke oven battery. } \\
\text { Coke side dedusting. } \\
\text { Coke quenching. }\end{array}$ \\
\hline Coal by-product & $\begin{array}{l}\text { Emission from leaks in process } \\
\text { lines, pumps, and apparatus, and } \\
\text { from loading operations of } \\
\text { carbon-based products. }\end{array}$ & $\begin{array}{l}\text { Emissions from venting of storage } \\
\text { and handling tanks and from a } \\
\text { flare stack. }\end{array}$ \\
\hline Sorting plant & $\begin{array}{l}\text { Emission from the sorting plant } \\
\text { by gravity ventilation systems, } \\
\text { grinding and screening } \\
\text { operations, loading into wagons. }\end{array}$ & Dedusting of sorting plants. \\
\hline
\end{tabular}

\section{Materials and Methods}

\subsection{Environmental Legal Regulations in the Field of Coke Production in the European Union}

In the BAT conclusions of the IED (IED-The Industrial Emissions Directive) Directive for coke oven plants, permissible levels of pollutants concentration, the so-called BAT-AEL's for selected substances from specific technological processes. They are arbitrarily defined in mentioned documents and synthetically presented in Table 2.

In addition, coking plants operating in the EU must also adapt their activities to the Directive on air quality, the so-called CAFE Directive [22], defining acceptable air quality standards presented synthetically in Table 3. These are the standards applicable to coking plants. 
Table 2. Permissible levels of pollutant emissions from coke oven plants in accordance with the BAT conclusions.

\begin{tabular}{|c|c|c|c|c|}
\hline Process & $\begin{array}{l}\text { Pollution } \\
\text { /Emission }\end{array}$ & Permissible Level & Unit & Comments \\
\hline \multirow{2}{*}{ Filling } & dust & $<5$ or $<50$ & $\begin{array}{l}\mathrm{g} / \mathrm{Mg} \text { of coke } \\
\text { or } \mathrm{mg} / \mathrm{Nm}^{3}\end{array}$ & - \\
\hline & visible emission & $<30$ & $\mathrm{~s}$ & $\begin{array}{l}\text { visible emission during } \\
\text { filling }\end{array}$ \\
\hline \multirow{4}{*}{ Firing of batteries } & SOx & $<200$ to 500 & $\mathrm{mg} / \mathrm{Nm}^{3}$ & $\begin{array}{l}\text { depending on the type of } \\
\text { firing gas }\end{array}$ \\
\hline & NOx & $<350$ to 500 & $\mathrm{mg} / \mathrm{Nm}^{3}$ & $\begin{array}{l}\text { for new plants or subject to } \\
\text { significant modernization }(< \\
10 \text { years })\end{array}$ \\
\hline & NOx & $<500$ to 650 & $\mathrm{mg} / \mathrm{Nm}^{3}$ & $\begin{array}{l}\text { for older plants with } \\
\text { properly operated batteries } \\
\text { and implemented } \mathrm{NO}_{X} \\
\text { emission abatement } \\
\text { techniques }\end{array}$ \\
\hline & dust & $<1$ to 20 & $\mathrm{mg} / \mathrm{Nm}^{3}$ & - \\
\hline Pushing & dust & $<10$ to 20 & $\mathrm{mg} / \mathrm{Nm}^{3}$ & $\begin{array}{l}\text { depending on the type of } \\
\text { filters used }\end{array}$ \\
\hline \multirow{3}{*}{ Quenching } & dust & $<25$ & $\mathrm{~g} / \mathrm{t}$ of coke & $\begin{array}{l}\text { in the case of conventional } \\
\text { low emission wet quenching }\end{array}$ \\
\hline & dust & $<20$ & $\mathrm{mg} / \mathrm{Nm}^{3}$ & $\begin{array}{l}\text { in the case of dry quenching } \\
\text { of coke }\end{array}$ \\
\hline & dust & $<10$ & $\mathrm{~g} / \mathrm{t}$ of coke & $\begin{array}{l}\text { in the case of quenching due } \\
\text { to flooding }\end{array}$ \\
\hline \multirow[b]{2}{*}{ Coking } & Visible emission & $<5$ to 10 & $\%$ & visible emission from door \\
\hline & Visible emission & $<1$ & $\%$ & $\begin{array}{l}\text { visible emission from } \\
\text { ascension pipes and charging } \\
\text { holes }\end{array}$ \\
\hline \multirow[b]{2}{*}{$\begin{array}{l}\text { Limiting the sulfur content } \\
\text { in the coke oven gas }\end{array}$} & $\mathrm{H}_{2} \mathrm{~S}$ & $<300$ to 1000 & $\mathrm{mg} / \mathrm{Nm}^{3}$ & $\begin{array}{l}\text { for desulfurization with } \\
\text { absorption systems }\end{array}$ \\
\hline & $\mathrm{H}_{2} \mathrm{~S}$ & $<10$ & $\mathrm{mg} / \mathrm{Nm}^{3}$ & $\begin{array}{l}\text { for wet oxidative } \\
\text { desulfurization determined } \\
\text { as the daily averages }\end{array}$ \\
\hline $\begin{array}{l}\text { Preparation of the charge } \\
\text { mixture-coal plant }\end{array}$ & dust & $<10$ to 20 & $\mathrm{mg} / \mathrm{Nm}^{3}$ & - \\
\hline $\begin{array}{l}\text { Storage and transport of } \\
\text { the coal blend }\end{array}$ & dust & $<10$ to 20 & $\mathrm{mg} / \mathrm{Nm}^{3}$ & - \\
\hline $\begin{array}{l}\text { Sorting and transportation } \\
\text { of coke }\end{array}$ & dust & $<10$ & $\mathrm{mg} / \mathrm{Nm}^{3}$ & - \\
\hline
\end{tabular}

Source: own study based on [20].

Both the provisions of the IED Directive (IED-The Industrial Emissions Directive) and the CAFE Directive are binding on all members of the European Union [23]. Coking plants are obliged to perform air pollutant dispersion calculations each time the integrated permit is updated or amended with reference to air quality standards. If it is shown that the permissible concentrations of pollutants in the air are exceeded as a result of the operation of the plant, corrective actions are proposed to reduce the emissions of a given substance. 
Table 3. Air quality standards.

\begin{tabular}{ccc}
\hline Pollution & Value & Unit \\
\hline Benzene & 5 & $\mu \mathrm{g} / \mathrm{m}^{3}$ \\
\hline PM10 & 40 & $\mu \mathrm{g} / \mathrm{m}^{3}$ \\
\hline $\mathrm{PM} 2.5$ & 25 & $\mu \mathrm{g} / \mathrm{m}^{3}$ \\
\hline $\mathrm{BaP}$ & 1 & $\mathrm{ng} / \mathrm{m}^{3}$ \\
\hline $\mathrm{NO}_{2}$ & 40 & $\mu \mathrm{g} / \mathrm{m}^{3}$ \\
\hline $\mathrm{SO}_{2}$ & 20 & $\mu \mathrm{g} / \mathrm{m}^{3}$ \\
\hline
\end{tabular}

Source: [16].

\subsection{Review of Guidance on Techniques to Abate Coke Plant Emissions}

The intention of introducing the conclusions on the best available techniques was to minimize the environmental impact of industrial plants. Relatively restrictive emission permissible values, the so-called BAT-AEL for specific production processes, compliance with which is to ensure the reduction of the environmental impact of industry. These quantities have been determined based on the emission abatement techniques listed in the Conclusions. A synthetic overview of the emission abatement techniques indicated in the reference document for coke production is provided in Table 4 [24].

However, these techniques do not constitute the full catalogue of possibilities to reduce the environmental impact of the plant [24]. The operators of plants may apply other methods of environmental protection, provided that the BAT-AEL emission levels are met [25]. In view of the continuous tightening of permissible levels for pollutants and the general trend of optimizing production systems for sustainability, the market for available emission abatement techniques and methods should therefore be monitored.

Table 4. Emission abatement techniques according to BAT conclusions.

\begin{tabular}{|c|c|c|}
\hline \multirow{2}{*}{ No. } & \multicolumn{2}{|c|}{ Conclusions Related to the Level of Emissions } \\
\hline & Conclusion No. & Proposed Emission Abatement Techniques \\
\hline 1. & $\begin{array}{l}\text { 42. BAT for coal plants (coal preparation } \\
\text { including crushing, pulverizing, grinding, and } \\
\text { screening) }\end{array}$ & $\begin{array}{l}\text { The techniques are designed to prevent or reduce dust emissions by } \\
\text { using one or a combination of the following techniques: } \\
\text { I. } \\
\text { airtight buildings and enclosed (airtight) equipment } \\
\text { (crushers, pulverizers, sieves) and } \\
\text { effective dust extraction, followed by the use of dry } \\
\text { dedusting systems. }\end{array}$ \\
\hline 2. & $\begin{array}{l}\text { 43. BAT with regard to the storage and transport } \\
\text { of a coal mix }\end{array}$ & $\begin{array}{l}\text { The techniques are designed to prevent or reduce fugitive dust } \\
\text { emissions by using one or a combination of the following techniques: } \\
\text { I. } \quad \text { storage of dusting materials in tanks and warehouses; } \\
\text { II. the use of closed or covered conveyors; } \\
\text { III. minimizing the height differences of coal transport routes } \\
\text { IV. abending on the size and structure of the plant; } \\
\text { V. } \quad \text { and the coal hopper; } \\
\text { Vemoving dust pollutants by dedusting. }\end{array}$ \\
\hline 3. & $\begin{array}{l}\text { 44. BAT with the aim of filling coke oven } \\
\text { chambers using low emission filling systems }\end{array}$ & $\begin{array}{l}\text { Generally speaking, the preferred types of filling are 'smokeless' } \\
\text { charging or sequential charging with double ascension pipes or } \\
\text { jumper pipes as all gases and dust are then removed in the coke oven } \\
\text { gas treatment process.However, where gases are removed and } \\
\text { treated outside the battery and independent of the raw gas } \\
\text { purification process, the preferred method is to treat by efficiently } \\
\text { trapping the gases and then incinerating them to reduce organic } \\
\text { compounds, and using a bag filter to reduce particulate matter. }\end{array}$ \\
\hline
\end{tabular}


Table 4. Cont.

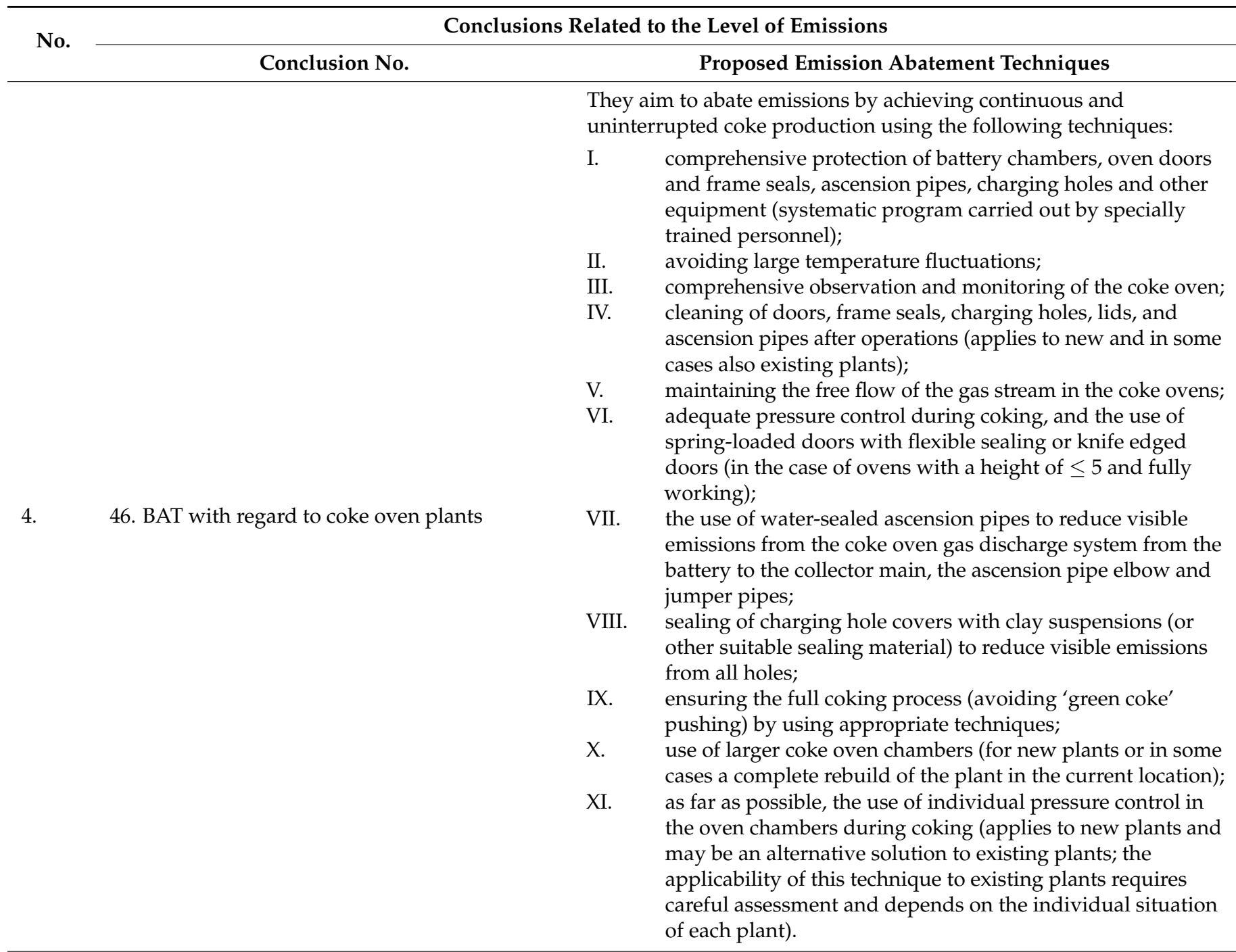

5. 48. BAT regarding sulfur content in coke oven gas (COG)
The techniques aim to reduce the sulfur content of the coke oven gas (COG) by using one of the following techniques:

I. desulfurization with absorption systems;

II. wet oxidative desulfurization.

They aim to abate emissions by using the following techniques:

I. preventing leaks between the coke oven chamber and the heating duct through even operation of the coke ovens;

II. removing leaks between the coke oven chamber and the heating duct (only applicable to existing plants);

6. 49. BAT with regard to the firing of the coke oven

III. implementation of low nitrogen oxide $\left(\mathrm{NO}_{\mathrm{X}}\right)$ emission techniques for the construction of new batteries, such as staged combustion, as well as the use of thinner ceramic fittings with better thermal conductivity (only for new plants);

IV. use of desulfurized coke oven gas (COG). 
Table 4. Cont.

\begin{tabular}{|c|c|c|}
\hline \multirow{2}{*}{ No. } & \multicolumn{2}{|c|}{ Conclusions Related to the Level of Emissions } \\
\hline & Conclusion No. & Proposed Emission Abatement Techniques \\
\hline \multirow{5}{*}{7.} & \multirow{5}{*}{ 50. BAT with regards to coke pushing } & They aim to abate dust emissions by using the following techniques: \\
\hline & & using a suction hood integrated with a coke transfer \\
\hline & & machine; \\
\hline & & $\begin{array}{l}\text { using gas treatment with a bag filter or other emission } \\
\text { abatement system; }\end{array}$ \\
\hline & & using a one point or mobile quenching car. \\
\hline
\end{tabular}

They aim to abate dust emissions by using one of the following techniques:

8. 51. BAT with regards to coke quenching
I. using coke dry quenching (CDQ) with the recovery of sensible heat and removal of dust from loading, transport and coke sorting operations using a bag filter;

II. using conventional low emission wet quenching;

III. using coke stabilization quenching (CSQ).

They aim to prevent or abate dust emissions by using a combination of the following techniques:

I. airtight buildings and enclosed (airtight) equipment;

II. effective dust extraction followed by dry dedusting.

They aim to use biological wastewater treatment with integrated nitrification / denitrification steps.

\section{0. from the coking process and coke oven gas} (COG) treatment
Conclusions related to technology

1. 45. BAT with regard to coking is to degas the coal blend as much as possible.

They aim to minimize fugitive gas emissions by using the following techniques:

I. minimizing the number of flanges by welding piping connections wherever possible;

II. using appropriate seals for flanges and valves;

III. using gas-tight pumps (e.g., magnetic pumps);

IV. avoiding emissions from pressure valves in storage tanks by:

- $\quad$ connecting the valve outlet to the coke oven gas (COG) collecting main or

- $\quad$ proper combustion of collected gas.

3. 53. BAT is to minimize the amount of quenching water and reuse it as much as possible.

4. 54. BAT is to avoid reusing process water with a significant organic content (e.g., raw coke oven wastewater, wastewater 4. with a high hydrocarbon content, etc.) as quenching water.

by using one or a combination of the following techniques:

I. using effective tar and polycyclic aromatic hydrocarbon (PAH) removal by using flocculation followed by flotation, sedimentation, and filtration, separately or in combination;

II. using effective ammonia stripping by using alkaline and steam.
55. BAT is to pretreat wastewater from the

5. coking process and coke oven gas (COG) treatment before discharge to the wastewater treatment plant [25]

6. 57. BAT is to recycle production residues, such as tar and residues from coal by-product plants, as well as excess sludge from the wastewater treatment plant to the coal feed of the coking plant.

7. 58. BAT is to use coke oven gas (COG) as a fuel or reducing agent or for the production of chemicals.

\subsection{Practical Methods and Tools for Abating Emissions in Coke Production}

The decision on the choice of emission abatement techniques relates to the investment process which, apart from purely technological purposes, should also meet the environmental assumptions. This means the practical implementation of the environmen- 
tal management model in which, in accordance with the guidelines of the Eco Management and Audit Scheme (EMAS) [25-29], environmental management is integrated into the overall enterprise management system with the inclusion of protective processes in the selection of techniques. Therefore, the decisions taken should, by definition, meet the environmental objectives at the lowest possible cost. An alternative solution may be the selection of ecologically beneficial techniques with imposed financial expenditures.

In practice, a simplified procedure is often used when selecting techniques to abate emissions in industrial plants. It consists in first selecting the source with the highest emissions. The technique is then selected from the list of techniques available for that source. The next step is to assess the availability of funds. At the end of the procedure, an economic analysis is performed that compares the drop in emissions with the cost of the selected technique $[30,31]$. The solution for which such a ratio is the highest is considered the most favorable [32].

In the analyses needed to obtain financing from external funds for the planned proenvironmental investment, the investor calculates the environmental effect [33]. The ecological effect for the considered project is most often expressed in the form of an equivalent emission, i.e., the product of the avoided emission and the toxicity index for a given pollutant $[34,35]$. An important element of the economic and ecological analysis for the coke plant is the creation of a database of emission abatement techniques [36]. This database contains data on techniques related to the effectiveness of emission abatement and the costs of their implementation.

Another method of assessing the techniques to be implemented is the method described in the guide for large combustion plants. This method was developed for the needs of the energy industry, mainly in order to justify the request for a derogation from adapting to the requirements of BAT conclusions for fuel combustion plants [37-40]. This guide uses the criterion of the environmental effect as a condition, the fulfillment of which has an impact on obtaining a derogation.

The above-described methods of calculating the effects of the application of the selected technique are limited to the identification of the emission decrease for a single emission source, but do not take into account the impact of the plant as a whole on air quality and the possibility of applying other techniques, often cheaper and providing a similar ecological effect. Meanwhile, the planning of environmental investments is primarily related to the need to adapt to legal regulations or the depletion of plants and the need to maintain production [41-43].

In light of the above considerations, it is not a big problem to indicate for a single emission source the most economically advantageous method of its abatement in order to meet the standards of the desired air quality. It most often consists in selecting the cheapest technique from among the available methods that abate emissions to the level that meets the standards $[44,45]$. A more difficult task, from the point of view of the decision-making methodology, is to meet the air quality standards for a larger group of emission sources [46].

In such a case, in order to make a decision, a list of emission abatement methods is prepared for each emitter, along with the amount of necessary investment expenditures. The use of selected techniques should ensure compliance with air quality standards and be characterized by the lowest cost.

The difficulty of selecting techniques in a situation where we deal with many emitters is related to:

- $\quad$ usually a large number of existing solutions leading to meeting emission standards;

- the necessity to meet air quality standards in the entire field of concentrations generated by the sources under consideration, often with a highly variable spatial nature;

- the impact of emission decrease in individual sources on the concentration values at various points in the concentration field, which is difficult to intuitively determine;

- a unit decrease in concentrations, obtained depending on the type of source, with a different cost. 
Meanwhile, as already mentioned, currently the selection of techniques is done individually and mainly due to the need to adapt to the requirements of BAT conclusions in technical and emission terms. Multi-variant analyses are not performed to determine as a whole the impact of the plant on air quality and the sequence of investments in specific techniques is not dependent on this. There are no comprehensive methods of selecting the best available techniques in the coke industry, taking into account ecological, technological, and economic criteria at the same time. From a practical and theoretical point of view, it is therefore necessary to constantly improve the selection of BAT and seek answers to the following research problem: How to identify, select, and choose BAT taking into account the multi-emission nature of coke production and multi-criteria decisions made in this regard (environmental, economic, and technological criteria)?

Taking into account the circumstances described above, the purpose of this article is to develop an algorithm of a procedure for the selection of the best available techniques to abate emissions from coking plants in the conditions of multiple emission sources, taking into account technological, environmental, and economic criteria. The developed algorithm of the procedure is aimed at enabling coke production managers to select techniques ensuring the protection of the atmospheric air against excessive pollution in the most economically advantageous manner, while using the best available technological solutions [47].

\subsection{Adaptation of the Scenario Method and Multi-Criteria Analysis for the Needs of a Detailed Research Methodology}

Identifying the research premises and specifying the main purpose of the research has become the starting point for the selection of research methods. The results of the studies and analyses undertaken in this area are presented in this subchapter in two main threads. The first one concerns the circumstances and principles of using the scenario method, while the second one refers to the multi-criteria analysis as a tool supporting the decision-making process in the conditions of the multiplicity and diversity of decision-making conditions.

Classically, in production management, the scenario method [48,49] is used to identify and then select possible decision-making solutions, which in this article was used to develop and characterize scenarios for abating emissions from the coke production process and selecting techniques for its abatement.

The main purpose of using the scenario method in the course of the research was to characterize various options for abating emissions from the coke production process, taking into account the multiplicity of its sources characterized, and to indicate the possibility of reducing it using BAT [5-51]. The development of these scenarios begins with the preparation of a comprehensive description of the tested facility (coking plant) along with important technical and environmental factors determining the production process. Then, environmental scanning is carried out, the purpose of which is to identify external factors that may affect the condition of the facility (coking plant) and the course of coke production, primarily including the level and dispersion of emissions. Detailed characteristics of the facility (coking plant) and its surroundings enable the synthesis of data and information on possible variants of the dispersion of emissions accompanying the production of coke, on the basis of which possible scenarios are generated. Subsequently, in relation to individual proposals, emission abatement techniques (BAT) are selected, for which technical and economic parameters of use are determined. Their final, comprehensive assessment is carried out on the basis of a multi-criteria analysis [52,53].

In the case of multi-criteria analysis, it is assumed that the final decision on the selection of the best available emission abatement technique in coke production should be made on the basis of environmental, technological, and economic criteria. In practice, their integration is problematic due to the dissimilarity and the multiplicity of the indicators adopted for assessment, but it can be successfully solved thanks to multi-criteria analysis, increasingly used in manufacturing enterprises $[54,55]$ which, in the current economic conditions, can no longer solely focus on the technological or economic aspects of production. In the literature on the subject, you can find many examples of the use of multi-criteria anal- 
ysis to solve technical and environmental problems, including in relation to construction production [56], food production [57], or energy production [58].

\subsection{Algorithm for Selecting Techniques to Abate Emissions (BAT) in Coke Production}

The original algorithm of emission abatement techniques is shown in Figure 4. It consists of three main stages, described in detail later in this article. The practical application of this algorithm will be described in the section on test results.

1. Development of the baseline scenario

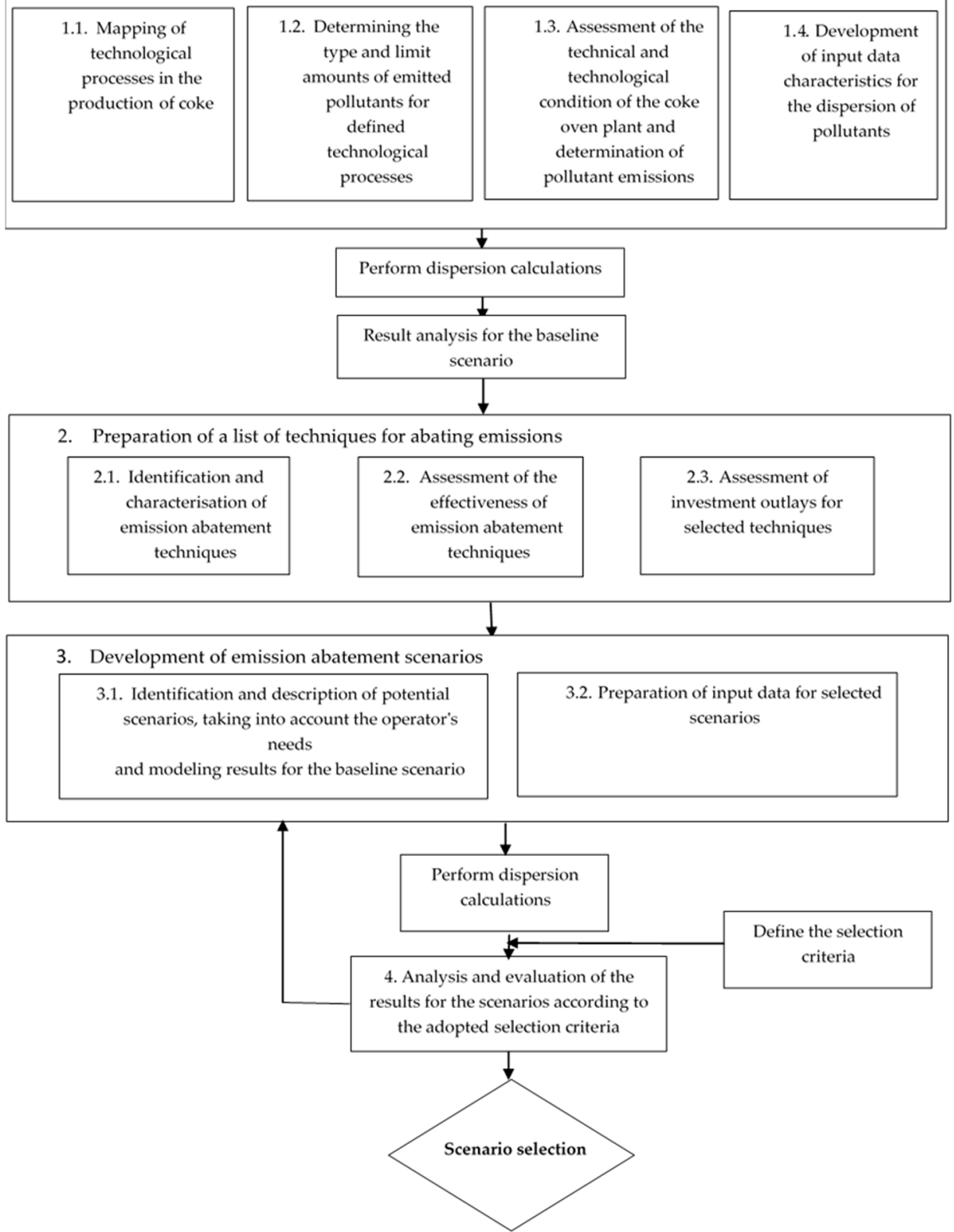

Figure 4. Algorithm for selecting techniques to abate emissions in coke production. Source: own elaboration.

Development of the baseline scenario (1) is the first step in the algorithm presented in Figure 4, leading to the selection of the best available techniques in coke production. At this stage, the determinants of emissions are identified and characterized, which can be divided into three groups:

1. process, relating to individual links in the coke production process (1.1); 
2. emission, relating to the type and scale of potential emissions in the coke production process (1.2);

3. technical and technological, characterizing the condition of the coking facility located in a given coking plant (1.3).

The results of this stage make it possible to identify environmental problems of the analyzed facility and are the basis for creating scenarios that take into account the technological, environmental, and economic conditions, and needs of the facility operator. The end result of this stage should be a map of the coke production process containing, apart from indicating the next production links, a list of the type and actual level of emissions with regard to its individual sources presented in Figure 1.

The starting point for obtaining such an effect is mapping the coke production process (1.1) in the technological and environmental context in accordance with the characteristics of emission sources from the coke production process presented in Table 1, which should be used as a checklist for individual stages of coke production and potential emission sources.

The next step is to determine the type and limit of the amount of pollutants emitted in the coke production (1.2). Each time, the selection of pollutants should be preceded by an analysis of documents containing environmental requirements for the production of coke. In relation to the above, in order to make the selection, the following should be analyzed:

- requirements of BAT conclusions in the scope of emission limit values and legal regulations concerning air quality standards,

- provisions from integrated permits (PZ),

- regulations on fees for the use of the environment.

For each identified pollutant, an analysis should be carried out to obtain detailed information on:

- the frequency of occurrence of emission restrictions in documents relating to emission levels from industrial plants,

- emission limit values,

- permissible concentrations in the air,

- the need to report as part of the periodic environmental reporting.

The result of the analysis of the above-mentioned data sources is a list of all pollutants indicated in these documents as characteristic of the coke production process.

The next sub-stage necessary to develop the baseline scenario is more individualized and consists in assessing the technical and technological condition of the coking plant and determining the amount of pollutant emissions from mapped technological processes (1.3). Such an assessment should be prepared with the use of the current technical documentation concerning the plant as well as the provisions of the environmental permits and the results of emission measurements.

Then, the actual amount of pollution is determined for the base state of a given coking plant. In this article, for the comprehensive implementation of this project, the assessment method developed for the purpose of determining the amount of emissions from coking plants within the European register of releases and transfer of pollutants to the environment, the so-called E-PRTR register, was used. This method makes it possible to adjust the emission factors to the individual technical and property level of a given coking plant, including, in particular, the basic equipment and technical condition as well as the applied emission abatement techniques. The estimation method is one of the emission balancing methods indicated for use in the E-PRTR system, and its additional advantage is the possibility of individualization necessary in the process of BAT selection in coke production described in the paper, which in practice depends on the technical and environmental equipment of a specific coking plant.

After mapping the coke production processes, identifying potential types of emissions and their actual levels in a given coking plant, we can proceed to the final stage of preparing the baseline scenario, which is the development of input data characteristics for the dispersion of pollutants in coke production according to the baseline scenario (1.4). 
The prepared input data is then entered into the selected calculation on program in order to conduct modeling of the dispersion of pollutants. The COPDIMO (Coke Plant Dispersion Model) program can be used for this purpose. This program is based on the Pasquill model, which is recommended in Poland as a model for calculating the impact of emissions from industrial facilities on the condition of the atmospheric air. For calculations, apart from the already mentioned COPDIMO program, you can also use available and commonly used calculation programs, such as: PROEKO or Ek100w [59-61].

After calculating the dispersion of pollutants for the baseline scenario, the obtained results are analyzed. The results are presented in the form of an image showing both the scope of the impact and the degree of pollution burden. For each substance, a graphical record of its annual emission, the highest average annual concentration, and the number of points with exceeding the permissible levels of air purity is obtained. The results from modeling the dispersion of pollutants are analyzed in terms of the number of exceedances of the permissible concentrations for selected pollutants in the air and the amount of emissions from a specific process, and are the basis for the development of scenarios of limiting the environmental impact of the plant by selecting the best available techniques.

The development of the baseline scenario enables the identification of stages and sources of emissions that require intervention and becomes the starting point for the second stage of the described algorithm, which is the preparation of a summary of emission abatement techniques (2). This step starts with the identification and characterization of emission abatement techniques (2.1). The following are used to prepare the database of techniques [62-65]:

- $\quad$ BREF (Best Available Technique (BAT) Reference Document) reference documents and BAT conclusions,

- offers from suppliers of techniques and equipment,

- available industry literature,

- the current state of equipment and wear of the analyzed plant in accordance with the assessment carried out under the baseline scenario.

In the list of techniques resulting from this sub-stage, it is necessary to determine what conclusions each of the selected techniques meets, which is a necessary condition to assess the possibility of its use in practice.

In addition to the Boolean evaluation of emission abatement techniques in the context of BAT conclusions, the next step is to assess the effectiveness of abating emissions of individual pollutants for selected techniques (2.2). The effectiveness of selected techniques can be determined on the basis of the available technical and technological materials and industry literature.

In addition to identifying the available abatement techniques and assessing their effectiveness, at the stage of preparing emission abatement techniques, we should also assess the investment expenditures for the selected techniques (2.3). Investment expenditures should be estimated on the basis of the current market conditions (market knowledge), taking into account the available solutions offered by individual producers $[66,67]$.

The results obtained from the environmental impact assessment of coking plants according to the baseline scenario (1) and the prepared list of emission abatement techniques (2) allow for the next stage of creating emission abatement scenarios (3) using the scenario method. The result of the implementation of this stage is a list of variant emission abatement scenarios along with their environmental impact assessment and the cost of their implementation.

The starting point for achieving the intended effect is the identification and description of potential scenarios, taking into account the operator's needs and modeling results for the baseline scenario (3.1).

The next step is to prepare the input emission data for the developed scenarios (3.2). The prepared emission data is entered into a calculation program for modeling the dispersion of pollutants in order to assess the impact of the plant after applying selected techniques. As a result of modeling, for each scenario, we obtain information on its 
impact on the environment in the form of the number of exceedances of the permissible concentrations of pollutants outside the plant. The operator receiving a summary of the results for the prepared scenarios has to choose the most favorable solution for them.

The obtained results are: the number of points with exceedances, the degree of fulfillment of BAT application and the investment cost of implementing the proposed techniques.

In order to select the best scenario, they should define the weights of the selection criteria. Establishing weights for the criteria is an important element in assessing the proposed scenarios for abating the environmental impact of plants. Weights can be assigned arbitrarily by the decision-maker or with the participation of experts in the field of the problem being solved.

In this article, to select the most favorable scenario, three criteria were used: environmental (the number of exceeded permissible concentrations of pollutants in the air), technological (the degree of meeting the BAT conclusions) and economic (the investment cost amount) [68-70].

The final stage is the selection of the best scenario (4) by the investor.

In order to make the best scenario, the obtained results are analyzed according to the adopted selection criteria and their weights. Each of the prepared emission abatement scenarios is assessed using coding, which consists in reducing the physical dimensions to dimensionless. Reducing the data to a dimensionless form allows for a comparative analysis and assessment of scenarios. The assessment of each of the prepared scenarios follows the following general scheme:

scenario assessment $=$

weight of the environmental criterion $\mathrm{x}$ environmental criterion +

weight of the economic criterion $\mathrm{x}$ economic criterion +

weight of the technological criterion $x$ technological criterion

The final effect of the comparative analysis is the indication of the scenario which obtained the highest number of points as a result of the conducted assessment, i.e., the most advantageous in terms of environment, economy, and technology.

\section{Results}

\subsection{Development of Emission Abatement Scenarios for the Tested Coke Oven Plant}

The operation of the algorithm is presented on the example of a model coke oven plant. The analyzed plant is in a poor technical and technological condition and does not meet the provisions of the BAT conclusions. The impact assessment for the (baseline) scenario shows that in the analyzed coking plant there is a big problem with $\mathrm{BaP}$ emission and, to a lesser extent, but equally burdensome with dust and $\mathrm{SO}_{2}$. High $\mathrm{BaP}$ emissions mainly come from the coking process, which is a continuous process. Due to the extensive depletion of the coke oven batteries and significant leaks in the holes and doors of the coking chambers, significant amounts of pollutants are emitted into the air.

In order to present the method of selecting the most favorable scenario, 10 examples of various emission abatement scenarios have been prepared for the analyzed plant. It was assumed that the scenarios will be of an investment, modernization, and renovation nature, meeting BAT conclusions to a different extent and will be characterized by different investment expenditures. The proposed scenarios mainly differ in the nature of the measures to abate emissions. The prepared scenarios include scenarios aimed at meeting $100 \%$ of the requirements of BAT conclusions as well as scenarios based on renovation and modernization activities that reduce the environmental impact of the plant to a different extent. The investor, having several scenarios at their disposal, has the opportunity to make a decision and plan the sequence of investments based on different variants of achieving the expected effect depending on the adopted criteria and selection weights. The characteristics and synthetic description of the scope of the proposed emission abatement measures are presented in Table 5. 
Table 5. Summary and description of emission reduction scenarios.

\begin{tabular}{ll}
\hline No. & Scope of the Scenario \\
\hline 1. & $\begin{array}{l}\text { Construction of } 5 \text { new batteries and dedusting } \\
\text { plants, new charging cars and new quenching } \\
\text { towers, desulfurization plant, dedusting of sorting } \\
\text { and coal plants }\end{array}$ \\
\hline & $\begin{array}{l}\text { Partial renovation of coke oven heads and the } \\
\text { adjustment, replacement of all doors using the } \\
\text { original solution, sealing of charging and } \\
\text { technological holes, inertial separator. }\end{array}$ \\
$2 . \quad \begin{array}{l}\text { Construction of } 2 \text { new batteries } 1,5, \text { partial } \\
\text { renovation of battery heads 2,3,4 with adjustment, } \\
\text { replacement of the door using the original solution } \\
\text { of batteries } 2,3,4, \text { sealing of charging and } \\
\text { technological holes, inertial separator }\end{array}$ \\
\hline 3
\end{tabular}

\section{Description}

A scenario without financial constraints, aimed at achieving the maximum environmental effect. Construction of all new facilities meeting the requirements of BAT conclusions.

A scenario involving activities often used with limited financial resources. Renovation works that do not meet the requirements of BAT conclusions. Reducing the environmental burden to a minimum extent.

A scenario covering both renovation and investment activities in new facilities. The solution is often used in multi-battery facilities. Combining investments with ongoing renovation works in order to gradually meet the requirements of BAT conclusions and abate the impact.

The scenario involves the construction of 3 new batteries without any action on other facilities. It is a quick check of the degree of limitation of plants when investing in the construction of new facilities. This

4. Construction of 3 new batteries $1,5,2$ type of solutions is rarely used in practice due to the high investment costs in the absence of meeting the BAT conclusions and the minimum ecological effect.

Construction of 3 new batteries 1,5,2, partial 5. renovation of heads 3,4 , replacement of the door using the original solution of batteries 3,4
A scenario aimed at checking the degree of emission abatement by combining investment works in new batteries and renovation works on the other two using original solutions. Activities focused on the abatement of emissions from the coking process and assessment of the degree of reduction of the plant burden.

The scenario in relation to scenario 5 is enriched with new solutions during renovation works. Activities focused on the abatement of emissions from the coking process. This solution is rarely used in plants.The scenario is aimed at a quick assessment of the degree of emission decrease through actions at selected facilities.

The scenario aimed at the maximum abatement of fugitive emissions from the coking process using only renovation works. This type of renovation work is often used on facilities with limited financial resources.

The scenario comprehensively combines renovation activities and the construction of new facilities. Including activities in the pushing and filling processes in this scenario has a significant impact on increasing the ecological effect and reducing the impact of the plant on air quality.

The scenario aims to determine the degree of reduction of the environmental impact of the plant by carrying out renovation works on the batteries with investment in new equipment during the pushing and filling process. The scenario aims to maximize the ecological effect of the coking, filling, and pushing processes with relatively low financial expenditures

The scenario in relation to scenario 9 was enriched with investments requiring large financial expenditures, such as the construction of a coke oven gas desulfurization plant and new quenching towers.

In order to select the most favorable scenario, Table 6 compares the obtained results according to the selection criteria adopted for the assessment. They were supplemented with the value of the technological criterion, namely the assessment of the degree of 
meeting the BAT conclusions in (\%), depending on the adopted abatement scenario and the techniques adopted therein, consistent with BAT. Compliance with the provisions of the BAT conclusions by the analyzed coking plant in the initial state, i.e., the baseline state, was estimated at $6.25 \%$. Depending on the techniques used, individual scenarios were assessed. Only according to scenario 1, the so-called model coking plant would meet the legal requirements $100 \%$ with the operation of the coking plant not exceeding the permissible concentrations of pollutants in the air.

Table 6. Summary of results for scenarios by selection criteria.

\begin{tabular}{|c|c|c|c|c|c|c|}
\hline Criterion & Economic & Technological & & Env & tal & \\
\hline \multirow{2}{*}{ Scenario } & \multirow{2}{*}{$\begin{array}{l}\text { Annual cost of the } \\
\text { techniques used (PLN/year) }\end{array}$} & \multirow{2}{*}{$\begin{array}{l}\text { Meeting the BAT } \\
\text { conclusions }(\%)\end{array}$} & \multicolumn{4}{|c|}{ Number of points with exceedances outside the coking plant } \\
\hline & & & $\mathrm{BaP}^{*}$ & $\mathrm{SO}_{2}$ & PM10 & $\mathrm{NO}_{2}$ \\
\hline baseline & - & 6.25 & 102 & 3 & 0 & 0 \\
\hline 1. & $73,577,500.00$ & 100 & 0 & 0 & 0 & 0 \\
\hline 2. & $7,894,500.00$ & 25 & 60 & 1 & 0 & 0 \\
\hline 3. & $21,203,366.67$ & 31.2 & 36 & 1 & 0 & 0 \\
\hline 4. & $24,000,000.00$ & 25 & 51 & 2 & 0 & 0 \\
\hline 5. & $26,693,333.33$ & 26.2 & 25 & 1 & 0 & 0 \\
\hline 6. & $28,240,000.00$ & 28.7 & 12 & 1 & 0 & 0 \\
\hline 7. & $10,600,000.00$ & 27.5 & 24 & 1 & 0 & 0 \\
\hline 8. & $32,758,700.00$ & 47.5 & 8 & 1 & 0 & 0 \\
\hline 9. & $18,131,166.67$ & 46.2 & 18 & 1 & 0 & 0 \\
\hline 10. & $40,777,833.33$ & 71.2 & 18 & 0 & 0 & 0 \\
\hline
\end{tabular}

${ }^{*}$ Due to the fact that the analyzed coking plant mainly has a problem with BaP emission and therefore the permissible concentrations are exceeded outside the premises, the environmental criterion will be included in the further assessment of the scenarios in relation to the number of BaP exceedances. Source: own work.

Analyzing the results, it can be noticed that the scenarios developed in the first place (1 and 2 ) differ significantly in the approach to investments in new equipment and facilities. The first scenario is a scenario mainly aimed at investing in new equipment and facilities that meet the BAT conclusions to the full extent and that are aimed at showing the decisionmaker what budget they would need to have in order to achieve such a state. On the other hand, scenario 2 is mainly based on renovation works and the application of the recommendations of the BAT conclusions to a limited extent. These are the scenarios in the summary: the most expensive and the cheapest, together with the ecological effect achievable for them. The assumptions adopted when creating the above-mentioned scenarios reflect the obtained results regarding the scope of the impact burden on the environment and meeting the BAT conclusions.

Other scenarios include a combination of investments in new equipment and facilities as well as renovation works. Such solutions are most often used by coke oven plant operators due to lower investment expenditures with a satisfactory ecological effect. Scenario 1 is the most favorable scenario in terms of meeting BAT conclusions and environmental impact. However, it stands out from the other scenarios in terms of the amount of investment expenditures necessary to achieve the ecological effect obtained. It is a scenario based on the construction of all new facilities and therefore not very realistic to be used by the investor due to the investment requirements and very high capital expenditures, while it is a scenario showing that zero exceedances in the vicinity of a coking plant are achievable in the absence of financial constraints. The creation of this scenario was aimed at estimating the amount of investment expenditures that a potential investor would have to take into account if they wanted to meet all the requirements of BAT conclusions with the currently owned plant in its baseline state and is treated as a model scenario, but not so realistic.

However, in practice, the decision-maker most often faces a decision problem in the form of the need to limit the environmental impact of coking plants on the one hand and limited available financial resources on the other. For this reason, scenarios 3 to 10 are scenarios more reflecting reality and are characterized by similar investment expenditures 
and a satisfactory environmental effect in relation to the baseline state. The environmental impact assessment for these scenarios shows that with comparable outlays, different environmental effects can be obtained, and these scenarios should be subject to comparative analysis.

\subsection{Assessment and Selection of Emission Abatement Scenarios in Coking Plants}

The article proposes a procedure scheme to support the decision-maker in making a decision on the selection of the most favorable scenario for abating the environmental impact, taking into account specific selection criteria and the weights assigned to them. Criteria weights were identified on the basis of the results of expert surveys. The survey was conducted among experts working in various capacities either directly in the coking industry or working in the field of coking. People from various stakeholder groups related to the coking industry were selected for the survey in order to cover all expert areas. Ultimately, the expert group included the following people:

- management of the coking plant,

- environmental protection specialists in the coking plant,

- production workers,

- $\quad$ experts from scientific entities,

- $\quad$ and people from the business environment related to the production of coke.

The averaged and rounded to the full value amount of weights for individual criteria established in the questionnaire surveys finally amounted to:

- $\quad$ environmental criterion: $45 \%$.

- $\quad$ economic criterion: $30 \%$.

- technological criterion: $25 \%$.

Such a distribution of weights reflects the priority of ecological adjustments that determine the current and future operation of coking plants dependent on meeting environmental requirements. In second place, in the adopted methodology, the experts indicated the economic criterion, which significantly limits investment opportunities in economic practice. Ranked in third place was the technological criterion, which, due to the market possibilities of obtaining specific technological solutions tailored to the individual needs of the operator, is a rational and justified indication.

After taking into account the weights of the criteria, the value of the total assessment score was calculated for each scenario. The results are presented in Table 7.

Table 7. Total evaluation of the scenarios with consideration of the criteria weights.

\begin{tabular}{lcccccccccc}
\hline \multirow{2}{*}{ Selection Criterion } & \multicolumn{1}{c}{ Scenarios } \\
\cline { 2 - 11 } & $\mathbf{1}$ & $\mathbf{2}$ & $\mathbf{3}$ & $\mathbf{4}$ & $\mathbf{5}$ & $\mathbf{6}$ & $\mathbf{7}$ & $\mathbf{8}$ & $\mathbf{9}$ & $\mathbf{1 0}$ \\
\hline Environmental & 0.450 & 0.000 & 0.180 & 0.068 & 0.270 & 0.360 & 0.270 & 0.387 & 0.315 & 0.315 \\
Economic & 0.000 & 0.300 & 0.237 & 0.225 & 0.213 & 0.207 & 0.287 & 0.186 & 0.252 & 0.147 \\
Technical & 0.250 & 0.000 & 0.020 & 0.000 & 0.004 & 0.012 & 0.008 & 0.075 & 0.070 & 0.153 \\
Total assessment & 0.700 & 0.300 & 0.437 & 0.292 & 0.487 & 0.579 & 0.565 & 0.648 & 0.637 & 0.614 \\
Ranking & 1 & 9 & 8 & 10 & 7 & 5 & 6 & 2 & 3 & 4 \\
\hline
\end{tabular}

Source: own work.

As a result of the adopted environmental criterion weighing $45 \%$, and the lack of financial constraints, according to the adopted assessment method, scenario 1 received the highest final point assessment (0.700) and is the most favorable scenario, which was mainly determined by the lack of points from exceedances and $100 \%$ compliance with the requirements of the BAT conclusions. Such a choice seems obvious and indisputable in the case of the availability of unlimited financial resources. However, as already mentioned, this is a model scenario and due to the amount of investment expenditures and the need to build all new equipment and facilities, it is not very realistic to implement for the existing coking plant. 
When analyzing further results of the assessment, it should be noted that the next scenario with the highest final assessment after taking into account the weights for the selected criteria is scenario $8(0.650)$. The high assessment for this scenario was due to the reduced number of points with exceedances from 102 to 8 in the baseline, after the implementation of the proposed emission abatement techniques and by over a half lower investment expenditure needed to achieve the ecological effect obtained compared to the expenditure for scenario 1 . As a result of the assessment, scenario 8 is the most favorable scenario apart from the model variant (scenario 1). Despite the lack of application of all the required BAT techniques, the coking plant, when implementing solutions according to scenario 8 , significantly abates the negative impact on the environment with relatively low capital expenditure.

Another scenario that stands out and is taken into account when deciding on the best scenario is scenario $9(0.640)$, the third according to the ranking. This scenario has a similar degree of fulfillment of BAT conclusions as scenario $8(46.2 \%), 10$ points more with exceedances (18), but $40 \%$ lower investment costs. It is a scenario characterized by a very good environmental effect in relation to the necessary incurred costs. The final selection of the scenario should be preceded by the analysis of the results obtained for the scenarios in terms of meeting the environmental, technical, and economic expectations of the decision-maker.

The remaining scenarios, which took the next places according to the final point assessment, will be described below. Scenario 10 is the fourth highest assessed scenario. This is the scenario with the highest degree of meeting the BAT conclusions and the highest investment cost after scenario 1 . The position in the ranking was determined by a high percentage of BAT conclusions (71.2) and a relatively good environmental effect (18). However, the same environmental effect can be obtained using the techniques of scenario 9 at half the expenditure. In the fifth and sixth place in the final assessment there are scenarios 6 and 7, which obtained a similar final assessment in order (0.580) and (0.560) and a similar percentage of meeting the BAT conclusions. By contrast, the environmental effect of applying the techniques according to scenario 6 , in the form of a twofold lower number of exceedances, is almost $60 \%$ more expensive. However, the fifth place in scenario 6 was determined by the high importance of the environmental criterion. The seventh place was achieved by scenario $5(0.490)$ characterized by a good environmental effect (25), comparable to the effect in scenario 7 (24), but with a significantly higher investment expenditure. Scenario 3 came eighth for the final assessment $(0.440)$. This place was mainly determined by the number of points with exceedances, which is the third highest number with exceedances.

The scenarios with the lowest final assessment according to the analysis are, in order, scenario 4 (0.290) and scenario $2(0.300)$. Scenario 2, despite the fact that it has the highest number of exceedance points and the lowest degree of meeting the BAT conclusions, did not receive the lowest total assessment. The fact that scenario 4 received the lowest assessment was determined by a large number of points with exceedances (51) and a three times higher annual expenditure with the same degree of meeting BAT conclusions $(25 \%)$ as scenario 2. Both scenarios are still characterized by high and comparable environmental burden. The use of BAT solutions in them is at the same level, while the expenditures for their implementation differ significantly.

The results of the analysis reveal the need for this type of analysis for various scenarios of abating industrial emissions. A similar environmental effect can be obtained with significantly different investment expenditures and degree of meeting the BAT conclusions. The results presented in this way constitute the information necessary for rational production management, taking into account the growing environmental requirements in relation to industrial plants. 


\section{Conclusions}

The presented method of selecting a scenario is universal and allows for a flexible selection of weights for the criteria depending on the needs and limitations of the investor at a given time, or to long-term plans to adapt to the increasingly stringent environmental requirements. This method can also be used in discussions with the authorities issuing integrated permits as regards the deadlines for adapting to legal requirements.

In relation to the existing theoretical and practical solutions in the field of BAT selection, the algorithm proposed in the paper enables:

- taking into account many emission sources related to coke production in the selection of techniques;

- reducing the difficulties associated with the presence of many emitters simultaneously;

- providing the decision-maker with a universal tool enabling the identification, selection, and final selection of BAT, taking into account all stages of coke production and the development strategy of the coking enterprise;

- reduction of the risk associated with the selection of an incorrect emission abatement technique, thanks to a holistic environmental analysis of coke production and simultaneous consideration of technological and economic criteria;

- improving the production processes of coking plants in terms of increasing environmental requirements in the European Union, which is of particular importance for the Polish economy, where coking is an industry of strategic importance;

- reducing the harmful impact of the coking plant on its environmental and social surroundings.

The practical possibilities of using the described algorithm are not only limited to the process of supporting investment decisions related to coke production. It can also be used as:

- a tool supporting environmental cost-benefit analyses necessary to carry out in the application process for the so-called temporary derogation from the requirement to comply with BAT conclusions in the coking industry;

- a set of guidelines for the preparation of a computer program to automate the process of selecting techniques to abate emissions from industrial plants in the coking industry;

- $\quad$ an instrument supporting the process of obtaining funds for the implementation of investments in the coking industry (thanks to a synthetic and understandable assessment of the effects of the implementation of a given investment and alternative investments);

- a universal approach to the BAT selection process in other industries (taking into account industry specific emission and technological criteria).

Author Contributions: J.T.-K.: conception, research; I.J.-K.: literature studies, description, conclusions. All authors have read and agreed to the published version of the manuscript.

Funding: This research was funded by Silesian University of Technology, grant number 13/010/ BK_21/0057.

Institutional Review Board Statement: Not applicable.

Informed Consent Statement: Not applicable.

Data Availability Statement: Not applicable.

Acknowledgments: The research was financed from Statutory research No. 13/010/BK_21/0057 (Institute of Economics and Computer Science, Faculty of Organization and Management, Silesian University of Technology).

Conflicts of Interest: The authors declare no conflict of interest. 


\section{References}

1. Air Quality in Europe-2020 Report; EEA Report No 09/2020. Available online: https:/ /www.eea.europa.eu/publications/airquality-in-europe-2019 (accessed on 1 February 2021).

2. Caruso, J.A.; Zhang, K.; Schroeck, N.J.; McCoy, B.; McElmurry, S.P. Petroleum Coke in the Urban Environment: A Review of Potential Health Effects. Int. J. Environ. Res. Public Health 2015, 12, 6218-6231. [CrossRef] [PubMed]

3. Vimercati, L.; Bisceglia, L.; Cavone, D.; Caputi, A.; De Maria, L.; Delfino, M.C.; Corrado, V.; Ferri, G.M. Environmental Monitoring of PAHs Exposure, Biomarkers and Vital Status in Coke Oven Workers. Int. J. Environ. Res. Public Health 2020, 17, 2199. [CrossRef]

4. Amodio, M.; Andriani, E.; Dambruoso, P.R.; de Gennaro, G.; Di Gilio, A.; Intini, M.; Palmisani, J.; Tutiono, M. A monitoring strategy to assess the fugitive emission from a steel plant. Atmos. Environ. 2013, 79, 455-461. [CrossRef]

5. Ptaszyński, P.; Mniszek, W. Potencjalne zagrożenie cyjanowodorem na terenie koksowni. Zeszyty Naukowe Wyższej Szkoły Zarzadzania Ochrona Pracy w Katowicach 2013, 19, 106-115.

6. Graham, J.D.; Holtgrave, D.R. Coke Oven Emissions: A Case Study of Technology Based Regulation. RISK Issues Health Saf. 1990, $1,243$.

7. Sobolewski, A.; Ściążko, M. Najlepsze Dostępne Techniki (BAT) Wytyczne dla Branży Koksowniczej; Wydawnictwo IChPW: Zabrze, Poland, 2006.

8. Farris, F. Coke oven emissions. In Encyclopedia of Toxicology; Elsevier: Amsterdam, The Netherlands, 2014; pp. 1003-1006.

9. Sobolewski, A. (Ed.) Uwalnianie i Transfer Zanieczyszczeń do Środowiska Będących Efektem Eksploatacji Instalacji Koksowniczych w Polsce; Wydawnictwo Instytutu Chemicznej Przeróbki Węgla: Zabrze, Poland, 2010.

10. Konieczyński, J. (Ed.) Właściwości Pyłu Respirabilnego Emitowanego z Wybranych Instalacji; Instytut Podstaw Inżynierii Środowiska Polskiej Akademii Nauk: Zabrze, Poland, 2010.

11. Telenga-Kopyczyńska, J.; Lajnert, R.; Bigda, R.; Sobolewski, A. E-PRTR jako system monitorowania poziomu emisji do powietrza na przykładzie instalacji koksowniczych. In Ochrona Powietrza w Teorii i Praktyce; Konieczyński, J., Ed.; Wydawnictwo Instytut Podstaw Inżynierii Środowiska Polskiej Akademii Nauk: Zabrzu, Poland, 2010; pp. 355-366.

12. Liberti, L.; Notarnicola, M.; Primerano, R.P. Air Pollution from a Large Steel Factory: Polycyclic Aromatic Hydrocarbon Emissions from Coke-Oven Batteries. J. Air Waste Manag. Assoc. 2006, 56, 255-260. [CrossRef]

13. Mu, L.; Peng, L.; Liu, X.; He, Q.; Bai, H.; Yan, Y.; Li, Y. Emission characteristics and size distribution of polycyclic aromatic hydrocarbons from coke production in China. Atmos. Res. 2017, 197, 113-120. [CrossRef]

14. Telenga-Kopyczyńska, J.; Lajnert, R. Uwalnianie zanieczyszczeń do powietrza będących efektem eksploatacji instalacji koksowniczych. Środowisko i Rozwój 2009, 202, 67-74.

15. Tuomi, T.; Veijalainen, H.; Santonen, T. Managing Exposure to Benzene and Total Petroleum Hydrocarbons at Two Oil Refineries 1977-2014. Int. J. Environ. Res. Public Health 2018, 15, 197. [CrossRef]

16. Directive 2008/50/EC of the European Parliament and of the Council of 21 May 2008 on Ambient Air Quality and Cleaner Air for Europe. Available online: https:/ / eur-lex.europa.eu/legal-content/en/ALL/?uri=CELEX\%3A32008L0050 (accessed on 1 February 2021).

17. Ciuffi, B.; Chiaramonti, D.; Rizzo, A.M.; Frediani, M.; Rosi, L. A Critical Review of SCWG in the Context of Available Gasification Technologies for Plastic Waste. Appl. Sci. 2020, 10, 6307. [CrossRef]

18. Kapała, J. Emisja Zanieczyszczeń Powietrza z Procesu Koksowania Węgla; Wydawnictwo ATH w: Bielsku-Białej, Poland, 2003.

19. Półka, M. An Analysis of Flammability and Explosion Parameters of Coke Dust and Use of Preliminary Hazard Analysis for Qualitative Risk Assessment. Sustainability 2020, 12, 4130. [CrossRef]

20. Commission Implementing Decision of 28 February 2012 Establishing the Best Available Techniques (BAT) Conclusions under Directive 2010/75/EU of the European Parliament and of the Council on Industrial Emissions for Iron and Steel Production (Notified Under Document C(2012) 903) (Text with EEA Relevance) (2012/135/EU). Available online: https:/ / eur-lex.europa.eu/ legal-content/EN/TXT/?uri=uriserv\%3AOJ.L_.2012.070.01.0063.01.ENG (accessed on 1 February 2021).

21. Sciążko, M.; Mertas, B.; Kosyrczyk, L.; Sobolewski, A. A Predictive Model for Coal Coking Based on Product Yield and Energy Balance. Energies 2020, 13, 4953. [CrossRef]

22. Dyrektywa Parlamentu Europejskiego i Rady 2008/50/WE z dnia 21 maja 2008 r. w Sprawie Jakości Powietrza i Czystszego Powietrza dla Europy. Available online: https:/ / eur-lex.europa.eu/legal-content/PL/TXT/PDF/?uri=CELEX:32008L0050\& from=DA (accessed on 1 February 2021).

23. Giljam, R.A. Extended application of 'best available techniques' as a means to facilitate ecological governance. J. Energy Nat. Resour. Law 2018, 362, 181-208. [CrossRef]

24. Decyzja Wykonawcza Komisji. z Dnia 28 Lutego 2012 r. Ustanawiająca Konkluzje Dotyczące Najlepszych Dostępnych Technik BAT Zgodnie z Dyrektywą Parlamentu Europejskiego i Rady 2010/75/UE w Sprawie Emisji Przemysłowych, w Odniesieniu do Produkcji Żelaza i Stali. Available online: https: / op.europa.eu/pl/publication-detail/-/publication/1b83d8f8-af75-4839-86729994ac23cb05/language-pl (accessed on 1 February 2021).

25. Kwarciak-Kozłowska, A.; Worwag, M. The Impact of an Ultrasonic Field on the Efficiency of Coke Wastewater Treatment in a Sequencing Batch Reactor. Energies 2021, 14, 963. [CrossRef]

26. Hamadeh, H.; Toor, S.Y.; Douglas, P.L.; Sarathy, S.M.; Dibble, R.W.; Croiset, E. Techno-Economic Analysis of Pressurized Oxy-Fuel Combustion of Petroleum Coke. Energies 2020, 13, 3463. [CrossRef] 
27. Kaiser, M. Emission reduction on coke oven and by-product plant. In Proceedings of the Eurocoke Summit, Vienna, Italy, 5-7 April 2011.

28. Telenga-Kopyczyńska, J.; Lajnert, R.; Sobolewski, A. Wytyczne dotyczace praktycznego zastosowania Konkluzji BAT w zakresie produkcji żelaza i stali. Sprawozdanie IChPW: Zabrze, Poland, 2016.

29. Honkasalo, A. The EMAS scheme: A management tool and instrument of environmental policy. J. Clean. Prod. 1998, 62, 119-128. [CrossRef]

30. Martins, F.; Fonseca, L. Comparison between eco-management and audit scheme and ISO 14001:2015. Energy Procedia 2018, 153, 450-454. [CrossRef]

31. Iraldo, F.; Testa, F.; Frey, M. Is an environmental management system able to influence environmental and competitive performance? The case of the eco-management and audit scheme EMAS in the European Union. J. Clean. Prod. 2009, 1716, 1444-1452. [CrossRef]

32. Burtraw, D.; Palmer, K.; Bharvirkar, R.; Paul, A. Cost-effective reduction of NOx emissions from electricity generation. J. Air Waste Manag. Assoc. 2001, 10, 1476-1489. [CrossRef]

33. Żeliński, J.; Telenga-Kopyczyńska, J. Social consequences associated with the use of various optimization methods in the protection of air quality. J. Environ. Plan. Manag. 2018, 626, 960-978. [CrossRef]

34. Xu, T.; Chen, Z.; Jiang, Z.; Huang, J.; Gui, W. A Real-Time 3D Measurement System for the Blast Furnace Burden Surface Using High-Temperature Industrial Endoscope. Sensors 2020, 20, 869. [CrossRef]

35. Abdulkareem-Alsultan, G.; Asikin-Mijan, N.; Lee, H.V.; Rashid, U.; Islam, A.; Taufiq-Yap, Y.H. A Review on Thermal Conversion of Plant Oil (Edible and Inedible) into Green Fuel Using Carbon-Based Nanocatalyst. Catalysts 2019, 9, 350. [CrossRef]

36. Zarzycki, R.; Kacprzak, A.; Bis, Z. The Use of Direct Carbon Fuel Cells in Compact Energy Systems for the Generation of Electricity, Heat and Cold. Energies 2018, 11, 3061. [CrossRef]

37. Yin, Y.; Han, X.; Wu, S. Spatial and Temporal Variations in the Ecological Footprints in Northwest China from 2005 to 2014. Sustainability 2017, 9, 597. [CrossRef]

38. Janik, A. Analiza możliwości zastosowania wybranych metod i wskaźników ekonomicznych, środowiskowych i społecznych w zrównoważonej ocenie technologii. Zeszyty Naukowe Politechniki Śląskiej, Organizacja i Zarzadzanie 2018, 115, 91-114.

39. Burchart-Korol, D.; Proksa, J. Metoda oceny środowiskowej projektów inwestycyjnych w gospodarce o obiegu zamkniętym. Zeszyty Naukowe Politechniki Ślaskiej Organizacja i Zarządzanie 2017, 68, 29-41.

40. Chornomaz, V.; Gawron, M.; Górska, D.; Iurkova, M.; Jędrzejczak, M.; Lewandowska, U.; Tarnas, A. Eco-efficiency as a problem in managing contemporary enterprises. Systemy Wspomagania w Inżynierii Produkcji 2016, 3, 52-58.

41. Kulczycka, J.; Smol, M. Application LCA for eco-efficiency assessment of investments projects. Acta Innov. 2015, 16, 29-38.

42. Yang, C.; Wu, H.; Deng, K.; He, H.; Sun, L. Study on Powder Coke Combustion and Pollution Emission Characteristics of Fluidized Bed Boilers. Energies 2019, 12, 1424. [CrossRef]

43. Janigacz, D.; Nitarska-Fink, A.; Wartak, B. Zmiany pozwoleń zintegrowanych—Wybrane problemy i wattpliwości. Energetyka 2019, 5, 346-349.

44. Górska, D.; Musiałowska, P.; Świstak, P. Nowoczesne instrumenty zrównoważonego rozwoju przedsiębiorstwa. Systemy Wspomagania w Inżynierii Produkcji 2018, 72, 76-82.

45. Gwizdała, J.P.; Kędzierska-Szczepaniak, A. Investment risks in financing pro-ecological projects-The dilemmas. Zeszyty Naukowe Akademii Morskiej w Szczecinie 2019, 60, 75-83.

46. Rosak-Szyrocka, J. Czystsza produkcja determinantą sukcesu środowiskowego przedsiębiorstw. Probl. Jakości 2018, 503, 9-17. [CrossRef]

47. Juda, J. Ewolucja Podejścia Do Zagadnień Ekonomicznych w Ochronie Powietrza; Wydawnictwo Politechniki Warszawskiej: Warszawa, Poland, 1997.

48. Warchałowski, A. Koszty Redukcji Emisji SO2. Politechnika; Wydawnictwo Politechniki Warszawskiej: Warszawa, Poland, 1997.

49. Cao, G.; Orru, R. Current Environmental Issues and Challenges; Springer Science \& Business: Berlin, Germany, 2014.

50. Slorach, P.C.; Jeswani, H.K.; Cuéllar-Franca, R.; Azapagic, A. Assessing the economic and environmental sustainability of household food waste management in the UK: Current situation and future scenarios. Sci. Total Environ. 2020, 710, 135580. [CrossRef]

51. Kanoniuk, A.; Magruk, A. Przegląd metod i technik badawczych stosowanych w programach foresight. Nauka Szkolnictwo Wyższe 2008, 232, 28-40.

52. Çankay, S.; Pekey, B. Application of scenario analysis for assessing the environmental impacts of thermal energy substitution and electrical energy efficiency in clinker production by life cycle approach. J. Clean. Prod. 2020, 270, 122388. [CrossRef]

53. González-García, S.; Bonnesoeur, V.; Pizzi, A.; Feijoo, G.; Moreira, M.T. Comparing environmental impacts of different forest management scenarios for maritime pine biomass production in France. J. Clean. Prod. 2014, 64, 356-367. [CrossRef]

54. Daszyńska-Żygadło, K. Podejście scenariuszowe w zarządzaniu ryzykiem. Uniwersytet Ekonomiczny we Wrocławiu Instytut Zarzadzania Finansami 2012, XLVI4, 76.

55. D'Souza, S.A.; Banik, S.; Vuthaluru, H.B.; Pisupati, S.V. Comparison of Natural and Synthetic Petroleum Coke Slag Viscosities under Reducing Conditions: Applicability of Predictive Models Using Factsage and Modified Urbain Model. Fuels 2021, 2, 3. [CrossRef] 
56. Rounsevell, M.D.A.; Metzge, M.J. Developing qualitative scenario storylines for environmental change assessment. Wiley Interdiscip. Rev. Clim. Chang. 2010, 14, 606-619, 391-401. [CrossRef]

57. Drury, C. Management and Cost Accounting, 7th ed.; Cheriton House: Hampshire, UK, 2007.

58. Nermend, K. Metody Analizy Wielokryterialnej $i$ Wielowymiarowej we Wspomaganiu Decyzji; PWN: Warszawa, Poland, 2017.

59. Song, S.; Hou, D.; Zhang, J.; O'Connor, D.; Li, G.; Gu, Q.; Li, S.; Liu, P. Environmental and socio-economic sustainability appraisal of contaminated land remediation strategies: A case study at a mega-site in China. Sci. Total Environ. 2018, 610-611. [CrossRef]

60. Li, X.; Li, J.; Sui, H.; He, L. Evaluation and determination of soil remediation schemes using a modified AHP model and its application in a contaminated coking plant. J. Hazard. Mater. 2018, 353, 300-311. [CrossRef]

61. Giner-Santonja, G.; Calvo, V.; Rodríguez, L.G. Application of AHP and corrective factors for the determination of best available techniques and emission limit values at installation level: A case study in four cement installations. Sci. Total Environ. 2019, 660, 834-840. [CrossRef]

62. Torres, E.R.; Doval, L.R.; Martínez, L.M.G.; Bugallo, P.M.G. Integrated environmental permit through Best Available Techniques: Evaluation of the dairy industry. J. Clean. Prod. 2017, 162, 512-528. [CrossRef]

63. Zapelloni, G.; Rellán, A.G.; Bello Bugallo, P.M. Sustainable production of marine equipment in a circular economy: Deepening in material and energy flows, best available techniques and toxicological impacts. Sci. Total Environ. 2019, 687, 991-1010. [CrossRef]

64. Wierzbińska, M. Modelowanie rozprzestrzeniania się zanieczyszczeń emitowanych z emitorów punktowych. Inżynieria Ekologiczna 2017, 182, 199-209. [CrossRef]

65. Żeliński, J.; Kaleta, D.; Telenga-Kopyczyńska, J.; Sobolewski, A. Zastosowanie programu COPDIMO do obliczeń rozprzestrzeniania się zanieczyszczeń z instalacji koksowniczych. KARBO 2014, 3, 112-119.

66. Telenga-Kopyczyńska, J.; Konieczyński, J. Perspektywy ograniczenia emisji pyłu, ditlenku siarki i tlenków azotu w wyniku zastosowania BAT w elektroenergetyce i ciepłownictwie w Polsce. In Aktualne Problemy Ochronie Powietrza Atmosferycznego; Musialik-Piotrowska, A., Rutkowski, J.D., Eds.; Polskie Zrzeszenie Inżynierów i Techników Sanitarnych: Warszawa, Poland, 2008; pp. 45-54.

67. Xu, Q.; Peng, W.; Ling, C. An Experimental Analysis of Soybean Straw Combustion on Both CO and NOX Emission Characteristics in a Tubular Furnace. Energies 2020, 13, 1587. [CrossRef]

68. Karwot, J.; Ober, J. Safety management of water economy. Case study of the water and sewerage company. Manag. Syst. Prod. Eng. 2019, 27, 189-196. [CrossRef]

69. Sakiewicz, P.; Piotrowski, K.; Ober, J.; Karwot, J. Innovative artificial neural network approach for integrated biogas-Wastewater treatment system modelling: Effect of plant operating parameters on process intensification. Renew. Sustain. Energy Rev. 2020, 124, 109784.

70. Ober, J. Innovation Adoption: Empirical Analysis on the Example of Selected Factors of Organizational Culture in the IT Industry in Poland. Sustainability 2020, 12, 8630. [CrossRef] 